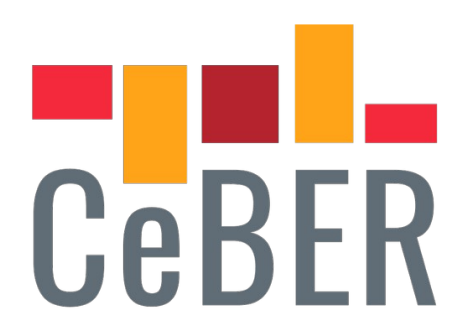

CENTRE FOR BUSINESS AND ECONOMICS RESEARCH

- UNIVERSITY OF COIMBRA

\title{
The consequences of intrapreneurship in exporting firms: a structural-model approach
}

\author{
Gonçalo Nuno Rodrigues Brás \\ Universidade de Lisboa , IN+, LARSyS, Instituto Superior \\ Técnico; Univ Coimbra, Center for Business and Economics \\ Research, CeBER, Faculty of Economics

\section{Miguel Torres Preto} \\ Universidade de Lisboa , IN+, LARSyS, Instituto Superior \\ Técnico
}

CeBER Working Papers

No. 6 / 2021 


\title{
The consequences of intrapreneurship in exporting firms: a structural-model approach
}

\author{
Gonçalo Rodrigues Brás iD goncalo.bras@tecnico.ulisboa.pt \\ IN+, LARSyS, Instituto Superior Técnico, Universidade de Lisboa, Av. Rovisco Pais, 1049-001 Lisbon - Portugal \\ Univ Coimbra, CeBER, Faculty of Economics, Av Dias da Silva 165, 3004-512 Coimbra - Portugal
}

Miguel Torres Preto iD

IN+, LARSyS, Instituto Superior Técnico, Universidade de Lisboa, Av. Rovisco Pais, 1049-001 Lisbon - Portugal

\begin{abstract}
A number of recent scientific articles have studied the relationship between entrepreneurial orientation (EO) and firm's performance, though not all came in the scope of international entrepreneurship (IE). Researchers often test mediating or moderating variables that help explain this relationship. The extensive academic findings lead us to a wide range of mediating/moderating variables and to a lack of consensus in this domain. This study is in scope of IE literature, and it aims to provide new and robust insights supported by consistent empirical findings and to adopt this structural-model approach as a reference in the absence of academic consensus. Specifically, the paper examines the contribution of intrapreneurship to both the firm's international orientation (IO) and performance in light of the IE guidelines. To this end, we examine how the EO of Portuguese exporters influences corporate performance taking into account the meditating effect of their IO on the EO performance association through structural equation modelling. Results confirm that IO positively and significantly mediates the relationship between EO and corporate performance. EO and IO were also found to have a direct and positive effect on corporate performance. These findings confirm the relevance of intrapreneurship and international commitment to a better organisational performance and gives us empirical support to conclude that effort taken in these domains could enhance the exporters' performance. Moreover, this study makes an empirical and theoretical contribution to the IE topic and therefore aims to be a reference to the literature in this domain.
\end{abstract}

Keywords: Intrapreneurship, Entrepreneurial orientation, International orientation, Performance, Exporting firms.

JEL codes: L26, L25 


\section{INTRODUCTION}

Not only has the intersection of entrepreneurship and international business now become an important research topic (McDougall-Covin, Jones, \& Serapio, 2014), but there has been an undoubted increase in international entrepreneurship studies (Coviello, Jones, \& McDougall-Covin, 2014). Notwithstanding, few studies have addressed the causal effect between entrepreneurship and internationalisation.

The intersection of entrepreneurship and international business - i.e. international entrepreneurship (IE) - is defined by Oviatt and McDougall (2005, p. 538) as 'the discovery, enactment, evaluation and exploitation of opportunities - across national borders - to create future goods and services'. Nevertheless, few studies have taken a holistic or integrated approach to entrepreneurship and international business. As such, the specific influence of entrepreneurship when exploring international opportunities and their effect on corporate performance remains unclear. Indeed, despite the strong link between entrepreneurial orientation (EO) and corporate performance confirmed in several studies by Rauch, Wiklund, Lumpkin, and Frese (2009), very little consideration has been given to the hypothetically mediating effects related to internationalisation domain on the relationship between EO and a firm's performance. This study is underpinned by the literature review and guided by the challenge from $M$. Hughes and Morgan (2007) to investigate the effects of possible mediators that confirm there is both a direct relationship between EO and performance and also a strong indirect relationship; our aim is to test international orientation (IO) as a mediator of the relationship between EO and the performance of Portuguese exporting firms. There are currently no studies that consider IO as a mediator of those variables.

To fill this gap, our work strives to shed light on the contribution of the firm's EO to leveraging the performance of Portuguese exporting firms mediated through IO. Predominantly based on an IE approach and using structural equation modelling, we test the relationship between EO - IO performance in the Portuguese export sector. Moreover, we examine the potential benefits firms obtain from EO to determine whether (or not) an effort made in this area could be seen as a profitable investment in Portugal. This approach draws attention to the added value of intrapreneurship in the scope of internationalisation and captures the interest of policymakers at the microeconomic level. From a competitive point of view, this contribution makes it possible to highlight the relevance of entrepreneurship in conjunction with internationalisation in the Portuguese economy and hence to bring new knowledge to extant literature. Given the current Portuguese economic situation, along with the periods of anaemic growth and recession over the last 15 years, there have been repeated appeals and institutional incentives for both entrepreneurship and economic internationalisation. Portugal is one of the OECD countries that has seen the start-up rate return to the pre-crisis level (OECD, 2014) and recently left the moderate innovator group of countries in the latest European 
innovation scoreboard and joined the group of strong innovators (European Commission, 2020). This suggests that Portugal is a suitable context to study the relationship between entrepreneurship and internationalisation and its effects on corporate performance.

The remainder of this article is structured as follows. In the next section, we revisit the concept of intrapreneurship and discuss the link between intrapreneurship and internationalisation, as well as its connection with performance. The methods section describes the nature of the data and the estimation techniques. The subsequent section presents the results based on descriptive information and this is followed by a discussion of the results and their implications. The paper concludes by setting out the main contributions of the research for international business and the implications for business management, identifying areas for further research and study limitations.

\section{LITERATURE REVIEW AND HYPOTHESES DEVELOPMENT}

\subsection{Intrapreneurship}

Depending upon the different stages of country development (Brás \& Soukiazis, 2019), entrepreneurship is regarded as a relevant mechanism for economic development (Acs \& Audretsch, 1988; Coulibaly, Erbao, \& Mekongcho, 2018; Wennekers \& Thurik, 1999) and the EO of

${ }^{1}$ Similarly, different concepts are used to describe entrepreneurship within organisations, such as: intrapreneurship (Pinchot, 1986), corporate entrepreneurship (Zahra, 1991), corporate venturing (Macmillan, Block, \& Narasimha, 1986), entrepreneurial orientation firms plays a significant role (Song, Wang, \& Parry, 2010). In fact, economic and business development is very dependent on the level of entrepreneurship in organisations (Antoncic, 2007).

Entrepreneurial activities within the existing organisations are usually known as intrapreneurship or corporate entrepreneurship (Agca, Topal, \& Kaya, 2012) but a wide range of concepts are used to describe them ${ }^{1}$. Intrapreneurship, that is, entrepreneurship within the company (Fitzsimmons, Douglas, Antoncic, \& Hisrich, 2005), refers to the development of a new business within the organisation (Martiarena, 2013; Parker, 2011) by exploiting a set of endogenous factors, without anyone needing to leave the company to promote its entrepreneurial spirit. When new initiatives or new deals are promoted outside of a company, we are dealing with entrepreneurship (Parker, 2011). Similar to the concept of intrapreneurship, Zahra (1991) defines corporate entrepreneurship as a process of creating new businesses through the innovation of products/services and / or processes with the aim of improving the financial performance and competitive position of an existing organisation.

Emphasising corporate entrepreneurship's intrinsic dynamics as a strategy, Ireland, Covin, and Kuratko (2009) defines it as a vision focusing on entrepreneurial behaviour that deliberately and continuously fosters the organisation's rejuvenation through the identification of new opportunities.

(Covin \& Slevin, 1989), internal corporate venturing (Zajac, Golden, \& Shortell, 1991) or internal corporate entrepreneurship (Schollhammer, 1982). 
Although several aspects related to corporate entrepreneurship are still unexplored, the main focus has been on revitalising innovation, creativity and leadership in the organisations (Kuratko \& Audretsch, 2013).

However, focused on the organisational conditions associated with entrepreneurship within the company (corporate entrepreneurship) or on the person who promotes entrepreneurial activities within the company (intrapreneurship), it is important to understand that entrepreneurship in organisations is a matter of degree (Antoncic \& Hisrich, 2003). Entrepreneurship must therefore be understood as a firm-level phenomenon - known as EO (Covin \& Miller, 2014) - that reflects the extent to which firms are innovative, proactive, and risk taking in their behaviour and management philosophies (Anderson, Covin, \& Slevin, 2009) ${ }^{2}$. Moreover, Antoncic and Hisrich (2003) confirm EO as an intrapreneurship stream and Morris, Webb, and Franklin (2011) argue that dimensions of EO determine the level of intrapreneurship in the organisation.

On the other hand, it should be noted that innovation is of the utmost relevance to the EO construct (Rutherford \& Holt, 2007); this was recently underlined by (HernándezPerlines, Ibarra Cisneros, Ribeiro-Soriano, \& Mogorrón-Guerrero, 2019, p. 1) who stated 'that innovativeness is a necessary and sufficient condition for entrepreneurial orientation'.

\footnotetext{
${ }^{2}$ In order to preserve the academic authenticity, we choose to maintain the author's terms throughout the literature review (intrapreneurship or corporate intrapreneurship) rather than to
}

\subsection{Intrapreneurship and internationalisation}

Corporate entrepreneurship is recognised as a potential route to promoting the company's competitiveness on a sustainable basis (Covin \& Miles, 1999). This entrepreneurial attitude has contributed to the growth of the business sector and of economies as a whole (Knight, 2000; Lu \& Beamish, 2001). McDougall and Oviatt (2000) developed the concept of IE, which establishes a direct relationship between internationalisation and entrepreneurship by combining the innovation, proactivity and risk inherent to the internationalisation process. Later, McDougall and Oviatt (2005) defined IE as the process of discovering, evaluating and exploiting opportunities in foreign markets for the future development of goods and services. 'As such, the needs for entrepreneurship and internationalisation may complement and reinforce each other' (Callaway, 2008, p. 6), highlighting the need to explore corporate entrepreneurship to foster the companies' international growth (Dess et al., 2003).

Resource Based Theory identifies the company's unique set of tangible and intangible resources that contribute to its exclusive tacit knowledge of its global opportunities and help leverage its competitive advantage (Peng, 2001). Indeed, a company's resources play a decisive role in its internationalisation (Teece, 1982). The Uppsala Model identified knowledge as the

standardise in one term. Whether referring to corporate entrepreneurship or to intrapreneurship, the focus is on the extension of entrepreneurial capabilities within the firms, that is EO. 
most important resource and a critical variable that will have a positive impact on sales growth in the international market (YliRenko, Autio, \& Tontti, 2002). However, there is still no consensus on the relation between knowledge, skills and internationalisation (Kuivalainen, Puumalainen, Sintonen, \& Kylaheiko, 2010) or between knowledge typologies and internationalisation (Mejri \& Umemoto, 2010). Nevertheless, the level and speed of committing resources to the foreign market is particularly important to the definition of different approaches to internationalisation. Indeed, on one hand, the theory of International New Ventures (INVs) explains a competitive position based on resource use and sale of products/services in different countries from the moment the company was founded (Oviatt and McDougall, 1994); on the other hand, the Stage Theory of Internationalisation, especially the Uppsala Model (Johanson \& Vahlne, 1977; Johanson \& Wiedersheimpaul, 1975), holds that this positioning is accomplished through the gradual commitment of a firm's resources in foreign markets and a process of continuous learning. That is, the speed of internationalisation is crucial to determine whether (or not) the firms follow the INV approach i.e. international at inception (Oviatt \& McDougall, 1994) or in their first eight years (McDougall \& Oviatt, 1996).

The theories and/or abovementioned approaches help us understand the relationship between intrapreneurship and its internationalisation process. Moreover, various studies show that corporate entrepreneurship contributes effectively to the speed of a company's internationalisation (Acedo \& Jones, 2007; Dimitratos, Plakoyiannaki, Pitsoulaki, \& Tuselmann, 2010). In the particular case of INVs, McDougall and Oviatt (2000) and Knight and Cavusgill (2004) confirmed the influence of corporate entrepreneurship in the international engagement of the company. Birkinshaw (1997) also emphasises corporate entrepreneurship's contribution to the companies' international success. Similarly, Knight and Cavusgil (2004) argue that EO should be instrumental to the development and approval of key organisational routines to succeed in the international markets. On the other hand, the internationalisation process is, in itself, an act of entrepreneurship due to the risk SMEs face when accessing foreign markets by seeking opportunities aimed at growth or reaching some equilibrium ( $\mathrm{Lu} \&$ Beamish, 2001).

Research has shown the influence of entrepreneurship on firm internationalisation, be it in technologically oriented small and medium-sized enterprises (SMEs) (Crick \& Jones, 2000), 'Born Global' firms (Knight \& Cavusgil, 2004) or in new ventures (Yiu, Lau, \& Bruton, 2007). On the other hand, specifically in the export sector, entrepreneurship is found to have a particularly significant impact on the internationalisation of SMEs operating in hostile environments (Ibeh, 2003; Zahra \& Garvis, 2000). In this vein and based on a case study, Christmann, Alexander, and Wood (2016) state that the activities of entrepreneurial owner-managers positively impact the firm's internationalisation and $\mathrm{Ou}-$ Yang, Chaisingharn, and Nguyen (2016, p. 1) 
confirm the 'influence of entrepreneurship on a company's export orientation and the degree of internationalisation'.

In addition, drawing on the findings of Ripollés-Meliá, Menguzzato-Boulard, and Sánchez-Peinado (2007) for a sample of 155 Spanish firms, it is hypothesised that EO has a positive influence on the IO of Portuguese exporters.

H1: A firm's entrepreneurial orientation has a direct and positive effect on its international orientation.

\subsection{Internationalisation and performance}

'The subject of corporate performance measurement has been approached from a variety of disciplinary perspectives within business' (Sirgy, 2002, p. 143); although in many academic fields it lacks a coherent body of theory (Marr \& Schiuma, 2003). Take internationalisation, for example: when a company considers entering a foreign market, one of its goals is to become profitable (Lin, Liu, \& Cheng, 2011) and, therefore, the relationship between performance and internationalisation is clearly established (Chen \& Hsu, 2010; Glaum \& Oesterle, 2007). Some conclusions on the relationship between internationalisation and performance can be drawn from the diverse articles available, despite the lack of current academic consensus (Powell, 2014).

Whereas Elango (2006) suggests a positive linear relationship between the two concepts, Brewer (1981) and Ramaswamy (1992) confirm the linearity of the relationship but conclude that it is negative. Moreover, some authors claim there is a convex relationship between internationalisation and performance (Capar \& Kotabe, 2003; Lu \& Beamish, 2001), and others argue that it is concave (Gomes \& Ramaswamy, 1999; Sullivan, 1994). Some studies show a cubic, or Sshaped, relationship between internationalisation and performance, (Contractor, 2007; Lu \& Beamish, 2004), while other authors found U-shaped (Rossmannek \& Rank, 2019), M-shaped (Almodóvar \& Rugman, 2014) or even Wshaped relationships (Fernández-Olmos, Gargallo-Castel, \& Giner-Bagües, 2016) in diversified contexts. Although very diverse (Ruigrok \& Wagner, 2004), a wide range of studies conclude there is a relationship between internationalisation and performance; however, some studies refute any kind of relationship (Hennart, 2007). IO does seem to lead to a higher corporate performance (Moen, Heggeseth, \& Lome, 2016; Zahra, Ireland, \& Hitt, 2000) either due to the influence of the international expertise commitment (Billing, Mukherjee, Kedia, \& Lahiri, 2010), greater exporter cooperation (Racela, Chaikittisilpa, \& Amonrat, 2007), innovation (Boermans \& Roelfsema, 2016), CEO attributes (W.-T. Hsu, Chen, \& Cheng, 2013), or the expansion into new geographic and product markets (Colpan, Delios, \& Hikino, 2013). Finally, Schwens et al. (2018) concluded in a meta-analysis study that the degree (and scope) of internationalisation and performance are positively related .

Thus, and based on the theoretical foundation that one of the advantages of internationalisation is that it improves the 
firm's performance (C.-C. Hsu \& Boggs, 2003), it is hypothesised that IO has a positive influence on the performance of Portuguese exporters:

H2: The IO of Portuguese exporters has a direct and positive effect on their performance

\subsection{EO and Performance: $I O$ as a mediator}

Performance is not only studied due to its relationship with internationalisation but also because of the link with entrepreneurship. Lumpkin and Dess (1996) propose that EO can have various effects (moderating effects, mediating effects, independent effects, interaction effects) on corporate performance. Moreover, researchers analysing a diverse number of industries under different circumstances have confirmed strong links between EO and firm performance (Rauch et al., 2009) over the years.

Various studies confirm a positive relationship between entrepreneurial business activities and organisational performance (Chang, 2000; Putniņš \& Sauka, 2019) and even state that performance may be the most important consequence of intrapreneurship (Antoncic \& Hisrich, 2001).

Similarly, intrapreneurship or corporate entrepreneurship is referred to as relevant to the revitalisation of the business performance (Antoncic \& Hisrich, 2004; Phan, Wright, Ucbasaran, \& Tan, 2009) and financial performance (Kreiser, Kuratko, Covin, Ireland, \& Hornsby, 2019; Zahra \& Covin, 1995; Zahra, Neubaum, \& Huse, 2000), and also to creating value (Mohamad, Ramayah,
Puspowarsito, Natalisa, \& Saerang, 2011). While Kuratko and Audretsch (2013) report that corporate entrepreneurship can be critical to boosting the productivity of global organisations, Provasnek, Schmid, Geissler, and Steiner (2017) argue that, in terms of sustainability, corporate entrepreneurship helps gain or maintain a benchmark position. Also in Portugal, Felício, Rodrigues, and Caldeirinha (2012) found intrapreneurship influences business performance.

A company's high entrepreneurial level is generally associated to their ability to achieve a competitive advantage that will lead to an increase in business performance (Rezaei, Ortt, \& Scholten, 2012). In fact, this in in line with Resource Based Theory, which shows that successful companies gain sustainable competitive advantages through access to high quality instruments and resources even though they appear to be scarce and inimitable (Ray, Barney, \& Muhanna, 2004). In this regard, Urbano, Álvarez, and Turró (2013) emphasise the importance of corporate resources to developing intrapreneurship. While little of the research on intrapreneurship takes a specific theoretical framework (Hornsby, Kuratko, \& Zahra, 2002), increasing focus has been given in recent years to the analysis of the resource combination and management that give business the right conditions to search for new opportunities and develop innovative actions (Castrogiovanni, Urbano, \& Loras, 2011), leading to more efficient processes (Meyskens, Robb-Post, Stamp, Carsrud, \& Reynolds, 2010). The current work addresses the relevance of resources to growth (Penrose, 1959) and high profits (Wernerfelt, 
1984) or to achieving a competitive advantage (Barney, 1991). Furthermore, a configurational approach to EO explicitly directed toward SMEs explains variance in performance better than a contingency model (two-way interactions) or a main-effects-only model (Wiklund \& Shepherd, 2005), which confirms the significant role of EO on corporate performance. Despite the limitations of the contingency model, Wiklund and Shepherd (2003) have already confirmed that knowledge-based resources increase the contribution made by EO to SMEs' performance. Consequently, we propose a positive relationship between EO and performance in the Portuguese export sector.

H3: The EO of the Portuguese exporters has a direct and positive effect on their performance

On the other hand, the relationship between EO and firm performance may not be as straightforward as expected and it seems that several authors keep searching for a range of variables that mediate or moderate this hypothetical effect: functional performances (Rezaei \& Ortt, 2018), absorptive capacity and improvisation ( $\mathrm{P}$. Hughes, Hodgkinson, Hughes, \& Arshad, 2018), product quality (Yang \& Ju, 2017), family governance (Lee \& Chu, 2017), knowledge intensity (Schwens et al., 2018) or dynamic capabilities and corporate entrepreneurship (Lim \& Kim, 2020).
Other studies are based on the IE concept, which is defined by a strategy combining 'innovative, proactive, and risk-seeking behaviour that crosses national borders and is intended to create value in organisations' (McDougall \& Oviatt, 2000, p. 903). With the same conceptual purpose, Zahra and George (2002, p. 262) argue that 'firms that internationalise their operations in innovative and creative ways stand to achieve significant gains that go beyond superior financial performance'. However, the IE approach remains a multi-layered and multidimensional complex process still requires extensive research (Etemad, 2017, 2018). Over these years, Authors may previously have been discouraged from testing IO as a mediator variable between EO and performance as IE explicitly reveals the relationship between entrepreneurship, internationalisation and performance. However, the IE approach tacitly suggests that $\mathrm{IO}$ might have a mediator ${ }^{3}$ role in the relationship between EO and performance. The IE approach directly led to this hypothesis, but in some way other studies indirectly help support it.

For instance, Zehir, Can, and Karaboga (2015) tested the mediation of EOPerformance through the differentiation strategy (and innovation), which has some items related to international commitment; this is similar to the study by Alegre and Chiva (2013) where they propose innovation performance as the mediator factor or to the study by Kollmann and Stöckmann (2014) in

${ }^{3}$ A mediator is a construct that 'represents the generative mechanism through which the focal independent variable is able to influence the dependent variable of interest.' (Baron \& Kenny, 1986, p. 1173) 
which they test exploratory innovation for the same purpose.

In this line, using data from 213 mediumto-large UK firms, Wang (2008) analyses the mediation of EO-performance by means of a learning orientation construct. If we understand internationalisation as a learning oriented process (Johanson \& Vahlne, 1977), we find that IO can also be tested as a mediator variable in the EO-performance relationship. Another study considered the mediation of EO (and market orientation)Performance through network ties (Boso, Story, \& Cadogan, 2013), which may influence internationalisation in different ways (Coviello \& Munro, 1997). According to network theory (Johanson \& Mattsson, 1986, 1988), in which networks are a bridging mechanism that allows for rapid internationalisation, it also makes sense to test whether IO can be a mediator variable in EO-performance relationship. As our sample includes Portuguese exporting firms, we believe IO can be an adequate mediator of the aforementioned relationship. To strengthen the hypothetical mediation effect of IO in our model, the link of EO and performance has been tested by several researchers in international domains (Brouthers, Nakos, \& Dimitratos, 2015; Jantunen, Puumalainen, Saarenketo, \& Kyläheiko, 2005; Knight, 2000; Semrau, Ambos, \& Sascha, 2016; Van Doorn, Heyden, Tröster, \& Volberda, 2015; Zahra \& Garvis, 2000). Some authors find that when firms decide to export, they develop a business innovation process entrepreneurship - which influences their business performance (Samiee, Walters, \& DuBois, 1993; Simmonds \& Smith, 1968).
Given the previous discussion, we can conclude that EO has a positive impact on IO, which, in turn, has a positive effect on firm performance. We thus hypothesize:

H3': IO positively mediates the path between EO and performance of Portuguese exporters

Figure 1 presents the structural model (base) to be tested and respective research hypotheses. 


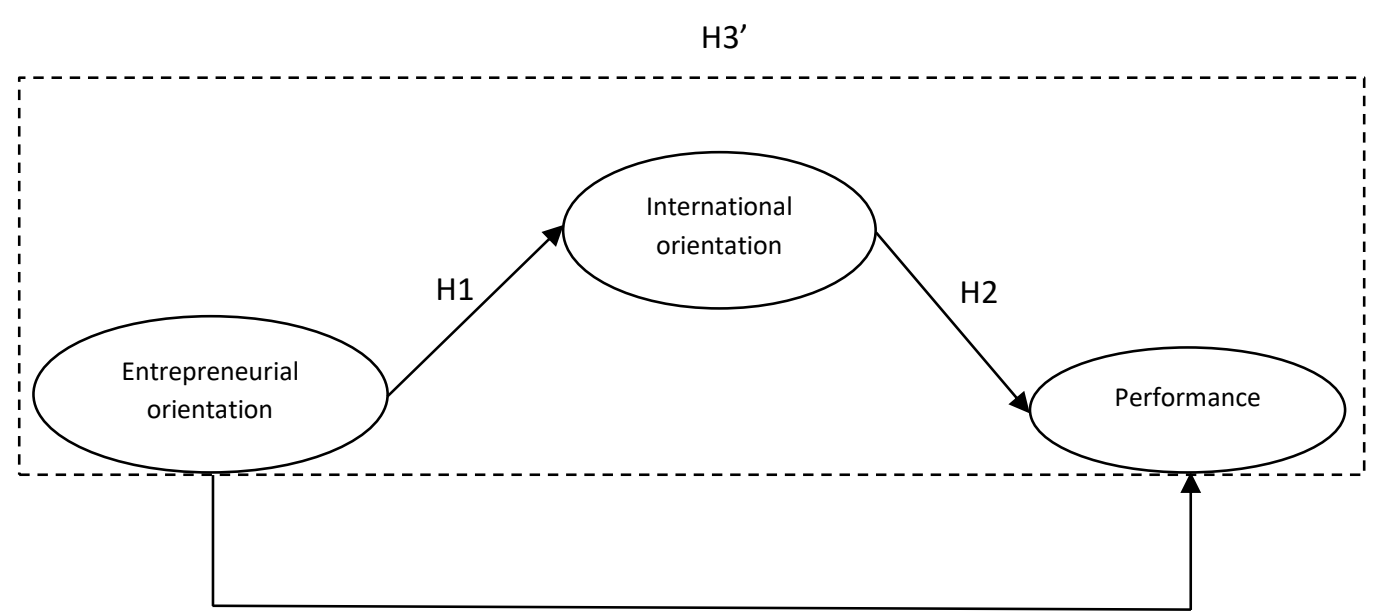

Figure 1: Structural model.

H3

\section{METHODS}

\subsection{Sample}

According to E-Informa Dun \& Bradstreet - Portugal official data, the universe of Portuguese exporters in 2013 comprised 46,562 companies. E-Informa Dun \& Bradstreet - Portugal was asked to provide a sample of 8,002 companies, i.e., $17 \%$ of the universe of export companies, respecting the activity sector standards of the Portuguese exporter universe. The sample is representative of this universe in terms of the company's size and business sector criteria. Applying the chi-square goodness of fit test with a significance level of 0.05 , there is no statistically significant difference between the universe and the sample ( $p$-value $\left(\chi_{12}^{2}=\right.$ $12,332)=0,419)$.

Due to various issues (incorrect email, company protection against unknown emails, etc), it was necessary to exclude 827 companies from the initial sample, thus leading to an updated sample of 7,175 companies. A total of 527 responses were collected from this sample, but only 350 were considered valid for our research (i.e. they were complete or had just one missing value in the variables included in the model).

Based on the valid data, the following set of characteristics of firms can be described: (i) company size, (ii) business sector, (iii) share of foreign sales in total revenue and (iv) number of years before the start of a business relationship in the foreign market (internationalisation). 
Table 1: Characteristics of the respondents (number of firms)

\begin{tabular}{|l|l|l|l|}
\hline Company size & Business sector & $\begin{array}{l}\text { Share of foreign sales in } \\
\text { total revenue }^{5}\end{array}$ & $\begin{array}{l}\text { Internationalisation } \\
\text { speed }^{6}\end{array}$ \\
\hline Microenterprise- 166 & Manufacturing -173 & $1-20 \%-112$ & Immediately -31 \\
Small enterprise -111 & Wholesale \& retail - 88 & $21-40 \%-62$ & Up to 3 years -122 \\
Medium-sized & Services - 38 & $41-60 \%-40$ & Up to 8 years -180 \\
enterprise -59 & Others ${ }^{7}-51$ & $61-80 \%-41$ & More than 8 years -146 \\
Large enterprise -14 & & More than 81\%-92 & \\
\hline
\end{tabular}

The Mahalanobis distance method, which detects and cleans existing outliers, was employed using a stringent alpha level of .001 (Kline, 2011); therefore, nine observations were removed and our sample size was reduced to 341 Portuguese exporters.

\subsection{Instrument}

A self-administered questionnaire was submitted to obtain primary information for the research. The questionnaire was pretested through a previous submission to 200 Portuguese exporter firms (randomly selected from the sample), from which feedback was received from 16 firms. After some slight changes, the final version of the questionnaire was available online on the LimeSurvey platform between February 15, 2015 and March 15, 2015. The questionnaire had four distinct sections: (i) company profile, (ii) EO, (iii) IO, and (iv) performance.

With the exception of the first section, all items in the questionnaire were in the form of statements rather than questions. This is a suitable approach when trying to measure attitudes, notably the company's entrepreneurial attitude towards the internationalisation process.

The first part of the questionnaire (company profile) consisted of questions on: (i) average number of employees in 2014 and (ii) statement of business activity sector. Likert scales were used ( 1 to 5 points) to measure all items in the second, third and fourth sections of the questionnaire. It is common practice to include both reversed and non-reversed items in multi-item Likert scales (Swain, Weathers, \& Niedrich, 2008); therefore reverse-polarity items are present in some factors, including in the IO scale adopted by Knight and Kim (2009) and introduced by us in the EO scale from Kreiser, Marino, and Weaver (2002). In order to maintain the coherence between EO and IO scales, in addition to maintaining the scope of the EO scale, we used the original scale sentences to make propositions about which respondents from Portuguese exporters assess their level of agreement - (1) strongly disagree to (5) strongly agree. The performance scale is rated on the

\footnotetext{
4 Micro firms employ less than 10 employees; Small-sized firms employ between 10 and 50 employees; Medium-sized firms employ between 51 and 250 employees; Large firms employ more than 250 employees.

5 Three missing values were reported.

${ }^{6}$ All incomplete questionnaires from firms who answered this question were also considered.

${ }^{7}$ Activities related to the primary sector, gas, electricity and water, construction, transports, housing and restauration, retail, financial activities, real estate activities and telecommunications.
} 
understanding of several corporate domains (1) very poor to (5) very good.

\subsection{Measures}

The scale proposed by Covin and Slevin (1989) was used to measure intrapreneurship; though sometimes adapted, it is the most commonly used scale to measure a company's EO (Kreiser et al., 2002) - 34 out of a total of 54 studies used the Covin and Slevin (1989) scale (B. A. George \& Marino, 2011). Thus, maintaining a similar structure to structure of the Covin and Slevin (1989) scale, a multidimensional construct was used that had been extensively tested in various countries (Kreiser et al., 2002) ${ }^{8}$.

A unidimensional scale was selected for the international dimension to avoid a more complex model. The Knight and Kim (2009) and Nummela, Saarenketo, and Puumalainen (2004) scales are the two unidimensional scales available to measure a firm's international orientation; we opted for the first (Knight and Kim 2009) of these due to its broader scope (11 items). This scale contains two items which are to be reverse scored (IO5 and IO6).

As our focus is on growth and profitability, we chose to measure the company's performance vis-à-vis that of its competitors. Following other studies (Baker \& Sinkula, 1999; Slater \& Narver, 2000), it was decided to use a multifaceted and unidimensional scale based on Farrell, Oczkowski, and Kharabsheh (2011), which includes five areas of performance: (i) customer loyalty, (ii) success of new products, (iii) sales growth, (iv) return on investment and (v) overall performance. Due to its nature, this scale cannot include reverse-polarity items.It was followed the eliminating items process from the abovementioned scales, which is common in empirical research (Wieland, Durach Christian, Kembro, \& Treiblmaier, 2017).

\subsection{Data analysis}

A first-order factor analysis was conducted to determine the effect of the indicators (measured in the questionnaire) on the latent variables (innovation, risk, proactiveness, IO and performance). This was followed by a second-order factor analysis to understand how the latent variables (innovation, risk and proactiveness) affect EO.

After defining the measurement model and performing the second-order factor analysis, the relations between exogenous and endogenous latent variables were established through a structural equation modeling (SEM). The SEM is appropriate for this research because of the complex model with multiple simultaneous variables and latent traits.

Various authors refer to SEM as a blended method of factor analysis with multiple regression (Ullman, 2007) in which a set of dependency relationships can be explored simultaneously (Hair, Black, Anderson, \& Tatham, 2005). Moreover, SEM has been used in other studies on intrapreneurship

${ }^{8}$ As proposed by Kreiser et al. (2002), the 9 th item from original scale measuring bold posture was dropped. 
(Antoncic, 2007) and analysing EO and international commitment (Ripollés, Blesa, \& Monferrer, 2012).

Some issues regarding the descriptive statistics from observed variables used in SEM should be highlighted. As can be seen in Appendix 1, the two items related to risk taking (risk1 and risk2) show the lowest average values, not only in the $\mathrm{EO}$ domain but also in all observable variables. Five items present average values above four points (Inov2, IO1, IO2, IO11, Perf1) and six items present average values below three points (Pro3, Risk1, Risk2, IO5, IO6, IO7). Furthermore, data dispersion can be analysed by the coefficient of variation, also known as relative standard deviation/error in which higher values indicate a relatively high dispersion of data. On this point, there is no consensual rule of thumb for this coefficient but if we take into account the threshold of $30 \%$ proposed by Brown (1998), we see that six items have values above that reference, and these are precisely the same items that present average values below three points. This indicates a relatively high variation of these items which would be a potential problem but, as explained and justified later in the paper, they will be removed from SEM. In relation to the univariate normality assessment, data are normally distributed if skewness is between -2 to +2 and kurtosis is between -7 to +7 (Byrne, 2013; Kim, 2013); data from Appendix 1 appear to meet the normality assumption.

However, depending on the possible violation of multivariate normality of the observed variables, as suggested by Byrne (2013) the bootstrap resampling method was used with 1000 replications, which is within the range (500 to 1000 replications) proposed by Cheung and Lau (2008). Therefore, we used the most common estimator in structural equation modelling, the maximum likelihood estimator (Marôco, 2010), applying AMOS software (version 24) with a previously defined $95 \%$ confidence interval.

Once the data does not rely on the assumption of normality, in line to the Preacher and Hayes (2008) recommendations we test the indirect effect of 'EO' factor in performance based on the bootstrap resampling (instead of the Sobel Test).

\section{RESULTS}

\subsection{Measurement model}

As the internal consistency by Cronbach's alpha and the Kaiser-Meyer-Olkin (KMO) measure revealed unsatisfactory results for the variables 'proactiveness' and 'risk', the multidimensionality of the latent variable 'EO' was not confirmed; this was therefore dropped and it was decided to work with the items (innovation, proactiveness and risk) on a unidimensional basis, as in the original scale proposed by Covin and Slevin (1989), despite not using the 9th item related to risk.

After assessment, some items of the three remaining factors (EO, IO and performance) did not show statistical significance. Some had low factor loadings $(\lambda \leq 0.5)$ and showed squared multiple correlation coefficients below the established cut-off value $\left(\mathrm{R}^{2} \leq\right.$ $0,25)$. Thus, in the 'EO' factor, two items related to proactiveness were removed (pro1 and pro3), as well as two items related to risk 
taking (risk1 and risk2). In addition, three items from the 'IO' factor were also removed (IO5, IO6 and IO7).

The modification indices (MI) were found to improve the model. Therefore, as suggested by MI values, correlations were made between the error terms of two pairs of variables from the 'IO' factor. These modifications do not affect the theoretical assumptions of the model, since correlations were made between the error terms from items that had a common factor, in this case the 'IO' factor.

It was also found that the 'customer loyalty' variable (Perf2), from the performance construct, was influenced by two factors, namely performance and EO. Hence, we opted to remove it to ensure a clearer definition of the model factors. Table 2 displays the estimation results of the measurement model following these procedures.

Table 2: Estimation results - measurement model

\begin{tabular}{|c|c|c|c|c|c|c|c|}
\hline Factor & $\mathrm{CR}^{9}$ & $\mathrm{AVE}^{10}$ & $\alpha^{11}$ & $\mathrm{KMO}^{12}$ & Items & $\mathrm{FW}^{13}$ & $\mathrm{SMC}^{14}$ \\
\hline $\begin{array}{l}\text { Entrepreneurial } \\
\text { orientation } \\
\text { Adapted from Kreiser } \\
\text { et al. (2002) }\end{array}$ & 0.834 & 0.560 & 0.74 & 0.742 & $\begin{array}{l}\text { (Inov1) In general, the top managers of my firm favour a } \\
\text { strong emphasis on R\&D, technological leadership, and } \\
\text { innovations. } \\
\text { (Inov2) In the past five years, my firm marketed many } \\
\text { new lines of products or services. } \\
\text { (Inov3) My firm usually promotes significant changes in } \\
\text { product lines / services offered. } \\
\text { (Pro2) My firm is very often the first business to } \\
\text { introduce new products/services, administrative } \\
\text { techniques, operating technologies, among others. }\end{array}$ & $\begin{array}{l}0.69 \\
0.77 \\
0.59\end{array}$ & $\begin{array}{l}0.47 \\
0.59 \\
0.35\end{array}$ \\
\hline $\begin{array}{l}\text { International } \\
\text { orientation } \\
\text { Adapted from Knight } \\
\text { and Kim (2009) }\end{array}$ & 0.918 & 0.588 & 0.87 & 0.892 & $\begin{array}{l}\text { (IO1) Top management tends to see the world, instead of } \\
\text { just Portugal, as our firm's marketplace. } \\
\text { (IO2) The prevailing organisational culture at our firm } \\
\text { (management's collective value system) is conducive to } \\
\text { active exploration of } \\
\text { new business opportunities abroad. } \\
\text { (IO3) Management continuously communicates its } \\
\text { mission to succeed in international markets to firm } \\
\text { employees. } \\
\text { (IO4) Management develops human and other resources } \\
\text { for achieving our goals in international markets. } \\
\text { (IO8) Our top management is experienced in } \\
\text { international business. } \\
\text { (IO9) Management communicates information } \\
\text { throughout the firm regarding our successful and } \\
\text { unsuccessful customer experiences abroad. } \\
\text { (IO10) Top management is willing to go to great lengths } \\
\text { to make our products succeed in foreign markets. } \\
\text { (IO11) Vision and drive of top management are important } \\
\text { in our decision to enter foreign markets. }\end{array}$ & $\begin{array}{l}0.79 \\
0.77 \\
0.63 \\
0.61 \\
0.69 \\
0.68 \\
\end{array}$ & $\begin{array}{l}0.59 \\
0.40 \\
0.37\end{array}$ \\
\hline $\begin{array}{l}\text { Performance } \\
\text { Farrell et al. (2011) }\end{array}$ & 0.917 & 0.742 & 0.86 & 0.799 & $\begin{array}{l}\text { (Perf1) Customer retention. } \\
\text { (Perf3) Sales growth. } \\
\text { (Perf4) Return on investment. } \\
\text { (Perf5) Overall performance. }\end{array}$ & $\begin{array}{l}0.53 \\
0.84 \\
0.85 \\
0.91\end{array}$ & $\begin{array}{l}0.28 \\
0.71 \\
0.72 \\
0.83\end{array}$ \\
\hline
\end{tabular}

${ }^{9}$ Composite reliability

${ }^{10}$ Average variance extracted

${ }^{11}$ Cronbach's Alpha

${ }^{12}$ Kaiser-Meyer-Olkin
${ }^{13}$ Factor weights (standardised)

${ }^{14}$ Squared multiple correlation 
As can be seen in Table 2, all items have high factor weights $(\mathrm{FW}>0.5)$ and show appropriate individual reliability $(\mathrm{SMC}>0.25)$.

Concerning the composite reliability (CR) from Dillon-Goldstein, according to Tenenhaus, Vinzi, Chatelin, and Lauro (2005) all factors have a good level since the demonstrated values range from 0.7 to 1. If we add the fact that the AVE values in all factors are greater than 0.5 , we can conclude according to Fornell and Larcker (1981) that there is convergent validity and, according to Hair et al. (2005), that all factors showed convergent validity and construct reliability.

Turning to the discriminant validity under the proposal of Fornell and Larcker (1981), as the AVE values of the three factors are always greater than the square of the construct's correlations, we conclude that all factors have discriminant validity. This is reinforced by the Heterotrait-Monotrait Ratio of Correlations (HTMT) matrix presenting values below 0.90 (liberal) or 0.85 (strict) thresholds suggested by Teo, Srivastava, and Jiang (2008) or by Kline (2011), respectively - see Appendix 2.

As for the internal consistency, given the Cronbach's alpha values listed in Table 3 (fourth column) and in line with the ranges set by D. George and Mallery (2010), we determined that the scales range from an acceptable level ('EO' scale) to a good level of internal consistency ('IO' and 'Performance' scales).

The sampling adequacy was good/excellent according to the ranges set by Kaiser (1974) given that the Kaiser-
Meyer-Olkin (KMO) measure in all factors is above 0.7 .

Finally, it is important to detect the potential of common methods bias because the questionnaire was filled by a single respondent. We used Harman's (1976) single-factor test before the factor rotation as recommended by Podsakoff, MacKenzie, Lee, and Podsakoff (2003). The results show that six factors explain $62.90 \%$ of the total variance, whereas the first factor explains only $28.38 \%$. It seems that data are uncontaminated by the biases of common method as many factors were identified in contrast to the single factor and, the first of these is not explanatory of most of the variance (Friedrich, Byrne, \& Mumford, 2009).

Although the univariate normality of the observed variables was confirmed, a necessary but not sufficient condition to ensure the multivariate normality - the Mardia's coefficient (1970) -, allows us to exclude the hypothesis of multivariate normality when its value is greater than three (Yuan, Marshall, \& Bentler, 2002). In our sample, the Mardia's standardised coefficient of multivariate kurtosis presents a critical value of 22.2 (much higher than the usual cut-off values of 1.96 or 3); we can therefore conclude that there is multivariate normality in the sample data.

We evaluated the measurement model on the basis of the adjustment indexes/parameters, which demonstrated a good overall fit $\left(\chi^{2} / \mathrm{gl}=1.734\right.$; RMSEA $=$ 0.046 ; $\mathrm{PCFI}=0.800 ; \mathrm{CFI}=0.970$; $\mathrm{TLI}=$ $0.964 ; \mathrm{NFI}=0.932)$.

Having tested and evaluated the basic characteristics of the measurement model, 
the following section analyses some details of the estimation and evaluates the structural model.

\subsection{Structural model}

Table 3 summarises the main results for the structural model (base), achieved through the bootstrap resampling method, which can be found in detail in Appendix 3 ; for the purposes of comparison, the results without bootstrap resampling are provided in Appendix 4. We can also see that, despite slight changes in the significance level, both estimations by maximum likelihood lead to the exact same conclusion, that is, with the desirable bootstrap resampling method (Appendix 3) due to infringement multivariate normality, or without bootstrap resampling (Appendix 4).

Table 3: Results of the estimation of the standardised parameters of the model

\begin{tabular}{|l|cccc|}
\hline Relationships & $\begin{array}{c}\text { Standardised } \\
\text { coefficients }\end{array}$ & $p$-value & Hypotheses & Results \\
\hline Entrepreneurial orientation $\rightarrow$ International orientation & $\mathrm{B} 1=0.677$ & 0.002 & $\mathrm{H} 1$ & Supported \\
International orientation $\rightarrow$ Performance & $\mathrm{B} 2=0.326$ & 0.002 & $\mathrm{H} 2$ & Supported \\
Entrepreneurial orientation $\rightarrow$ Performance & $\mathrm{B} 3=0.189$ & 0.047 & $\mathrm{H} 3$ & Supported \\
& & & &
\end{tabular}

The Figure 2 depicts the structural model, the standardised coefficients and established between the latent variables significance levels of the relationships

(Figure 2).

$0.221 * * *$

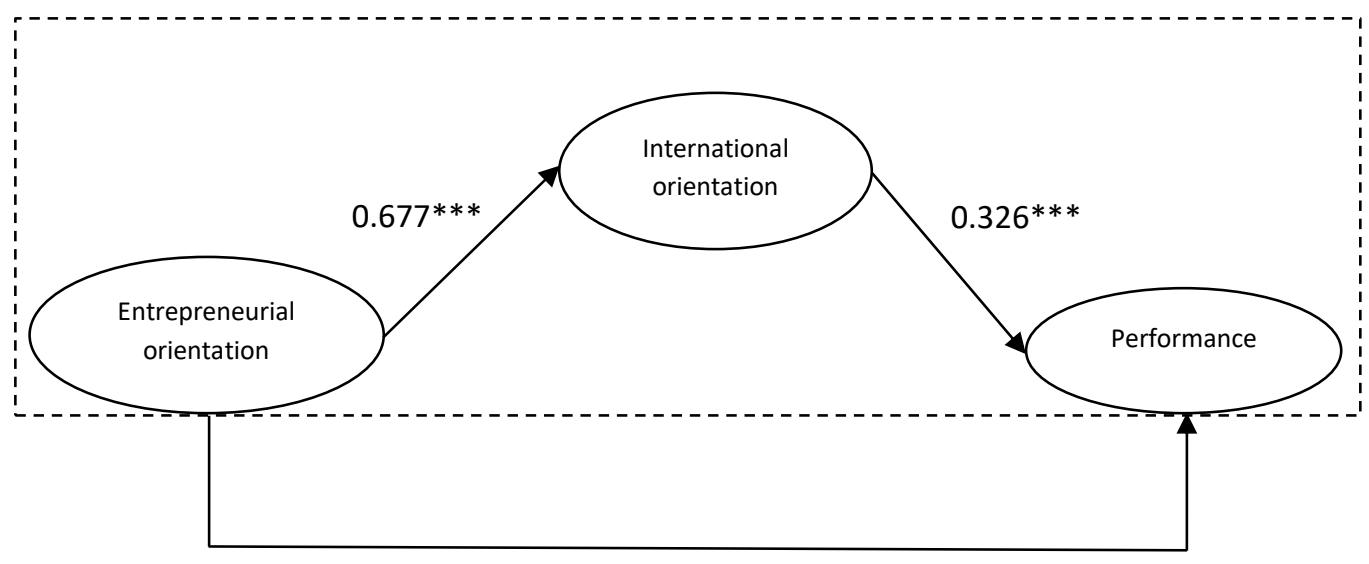

$0.189 * *$

Figure 2: Structural model results (base model)

**The coefficient is significant at the 0.05 level; ***the coefficient is significant at the 0.01 level 
Table 3 and Figure 2 show that results confirm all the hypotheses proposed in the theoretical model. Analysing the paths between factors, we see that the 'Entrepreneurial orientation - International Orientation' path has the greatest impact, followed by the 'International orientation Performance' path, and both are statistically significant at the $1 \%$ level. Finally, the 'Entrepreneurial orientation Performance' path is statistically significant at the 5\% level. To sum up, for a $1 \%$ significance level, we can accept hypothesis 1 'The entrepreneurial orientation of Portuguese exporters has a direct and positive effect on their international orientation', as well as hypothesis 2 'The international orientation of the Portuguese exporters has a direct and positive effect on their performance'.

Hypothesis 3 'The international orientation of the Portuguese exporters has a direct and positive effect on their performance' is also accepted given a 5\% significance level. To achieve this direct effect, we rejected the null hypothesis ( $p$ value $<0.01$ ) by bootstrapping that the product of the standardised coefficients of hypotheses 1 and 2 would be zero (B1 x $\mathrm{B} 2=0$ ).

With a significance level of $1 \%$, we can also conclude that the 'EO' factor, mediated by the 'IO' dimension has an indirect and positive effect on the 'Performance' factor 15; therefore hypothesis 3' is also confirmed. As such, the overall effect of the 'EO' factor on the 'performance' factor is 0.41 points $(0.189$
+0.221 ). For Portuguese exporters, this means that the indirect effect mediated by IO is stronger than the direct effect of EO on their performance. Similarly to the measurement model, structural model also shows a good overall fit $\left(\chi^{2} / \mathrm{gl}=1.715\right.$; RMSEA $=0.048 ;$ PCFI $=0.801 ;$ CFI $=$ 0.963 ; $\mathrm{TLI}=0.954$; NFI $=0.929$ ).

\section{DISCUSSION}

Firstly, descriptive statistics findings reflect an added value that contribute to the discussion of the international tendencies/paths in the Portuguese export sector. Table 1 shows that only $9.5 \%$ of the companies in the Portuguese export sector had some kind of relationship with the external market from start-up and approximately $45 \%$ developed this relationship only after the eighth year of activity. Given that a significant proportion of these companies initiate their international expansion so late, this shows that even though this sector is vocationally oriented to the external market, it does not follow INV guidelines or the Born Globals approach. To shows this evidence, the Appendix 1 clarifies that the items 'Management believes that, due to the nature of the international business environment, it is better to explore it gradually via conservative, incremental steps' (IO6) and 'In general, the top managers of my firm believe that due to the nature of the international business environment, it is better to explore it gradually via timid, incremental steps'

\footnotetext{
${ }^{15}$ The product of the standardised coefficients measures this indirect effect $(0.677 \times 0.326=0.221)$ and it is statistically significant at the $1 \%$ level (see Appendix 5).
} 
(Risk 1) belong to the lower average scores. In practice, this means that respondents from Portuguese exporter firms agree/strongly agree with these propositions, which were reverse scored and therefore presented low average scores. Broadly speaking, this shows that the Portuguese export sector is following some of the principles of the Uppsala Model (Johanson \& Vahlne, 1977; Johanson \& Wiedersheimpaul, 1975) instead of the INV approach.

The multidimensionality of the EO scale was not confirmed, as in the case of the study by J. Ferreira (2007) on the Portuguese economy. Moreover, even maintaining the core items (HernándezPerlines et al., 2019; Rutherford \& Holt, 2007), a more robust demonstration of the EO construct validity and/or reliability would be desirable; in fact, the two items related to risk had to be removed due to their low factor loadings and low individual reliability. This evidence indicates that Portuguese exporters display a high level of risk aversion. In fact, when comparing to other countries such as Brazil or Poland, Portuguese firms tend to be less risk takers (Duarte, Diniz, Arent, \& Bojar, 2013; A. d. S. M. Ferreira, Loiola, \& Gondim, 2017) and eventually Portuguese national culture does not encourage risk-taking (Carvalho, Simões, Samagaio, \& Couto, 2012). Nowadays, there is evidence of this risk aversion in the Portuguese economy generally, as previously defended by Burton (2015)?

Taking into account the structural model, it should be noted that the results confirm all the research hypotheses. They show that the role of intrapreneurship in
Portuguese exporters is directly related to their IO, that is, EO contributes positively to their IO. Moreover, this interaction confirms the conclusions of RipollésMeliá et al. (2007) who suggest that an EO positively influences firms to engage in international activity. This highlights the need to explore intrapreneurship as an instrument to further companies' international growth (Dess et al., 2003).

The positive effect of IO on the Portuguese exporters' performance is also confirmed by the empirical findings. A higher level of $\mathrm{IO}$, intrinsic to the Portuguese export sector, is indicative of a better performance. Moreover, these conclusions are in line with related bibliometric studies for SMEs (Pangarkar, 2008), for multinational enterprises (Loncan \& Nique, 2010) and in general (Ruigrok \& Wagner, 2004). Also, data on EO show it has a positive and indirect effect on the performance of Portuguese exporters, mediated by the IO factor, on their performance and that there is also a direct, positive effect between the two factors. As the indirect effect mediated by the IO factor is stronger than the direct effect between EO-Performance, we believe and in line to the findings of Pinho and Prange (2016) that IO acts as a dynamic capability in Portuguese exporters and therefore strengthens the relationship between EO and Performance. Nowadays, the theoretical framework confirms the diversity of studies searching for a mediator variable that helps explain this relationship. Taking into account recent contributions in this domain, it is possible to conclude that this remains an academic challenge. Is IO the 
missing link in the EO-performance relationship? Is our empirical approach valid way of understanding IE from a different perspective? If so, could our model be applied in other business contexts with the same results?

Finally, this study suggests EO contributes positively to corporate performance, particularly due to its distinctive innovative nature. The positive contribution made by innovativeness to corporate performance has been demonstrated in several studies in different contexts (Kilic, Ulusoy, Gunday, \& Alpkan, 2015; Kyrgidou \& Spyropoulou, 2013; Lintukangas, Kähkönen, \& Hallikas, 2019). Rutherford and Holt (2007) and Hernández-Perlines et al. (2019) underline innovativeness as the main key of the EO construct and are therefore in line with our findings; indeed, this has also been found to be the case in other Portuguese studies (Franco \& Haase, 2013).

\section{CONCLUDING REMARKS}

Given that the Portuguese export sector's commitment to the international market was predominantly gradual, it is understood that the assumptions of Uppsala Model govern the internationalisation process of the industry.

It was confirmed that EO contributed positively to a stronger IO of companies in the Portuguese export sector and also to better performance. IO was also found to have a positive effect on corporate performance in this sector.
The confirmation of the research hypotheses proved the critical role that intrapreneurship can take as leverage for internationalisation and as a driver of organisational performance. Although the overall findings reinforce the international business framework, it seems reasonable from the business management point of view to see intrapreneurship and international commitment as relevant to the increase in organisational performance. Hence, attempts made by companies to develop these strategic areas should be viewed as an investment in the future which will be reflected in their performance levels, and as suggested by Pinho and Prange (2016) international commitment might be considered a dynamic competence in this domain.

We are aware of the 'degree of complexity arising from the impact of a number of influential factors and forces affecting IE' (Etemad, 2017, p. 236). Still, our modest proposal makes several theoretical and empirical contributions in favour of a deeper discussion of the IE topic. Above all, IO was confirmed as a reliable link between the relationship between EO and Performance in the Portuguese export sector. Therefore and based on this evidence, we believe that further studies might explore this empirical approach, which aims to enrich the IE domain and serve as a reference.

As IO is the critical variable in our study and, in line with Cumming, Fischer, and Peridis (2015), is considered a strategic competence or a dynamic capability within firms, further research is needed to test the robustness of our model and determine whether there any 
difference between the firms that internationalise with the support of coaching or other government assistance and the other firms that receive no public support. Also, we strongly recommend testing our model in different industries or economic sectors.

On the other hand, as this study shows that innovation is the pillar of the EO construct, a potential path for further research is that of distinguishing between internal innovativeness and external innovativeness. This approach would allow an accurate assessment to be made of the role of innovation in a firm's international commitment and its contribution to high performance levels.

Finally, the following limitations of the study should be taken into account. As the research questionnaire was selfadministered, we had no 'control' over who was filling it in. Within the context of the universe of Portuguese exporters, reference should be made to the low number of responses obtained as this affects the confidence level and margin of error of the study. Furthermore, the study covers only a specific period in time and a longitudinal study might be explored to confirm, or reject, our results. On the other hand, the EO construct shows lower robustness than other constructs in the proposed model, although some validity problems have already been reported in the EO construct in Portuguese firms (Rodrigues \& Raposo, 2011). 


\section{REFERENCES}

Acedo, F. J., \& Jones, M. V. (2007). Speed of Internationalization and Entrepreneurial Cognition: Insights and a Comparison between International New Ventures, Exporters and Domestic Firms. Journal of World Business, 42(3), 236-252. doi: http://dx.doi.org/10.1016/j.jwb.2007.04.012

Acs, Z., \& Audretsch, D. B. (1988). Innovation in Large and Small Firms: An Empirical Analysis. The American Economic Review, 78(4), 678-690. doi: 10.2307/1811167

Agca, V., Topal, Y., \& Kaya, H. (2012). Linking intrapreneurship activities to multidimensional firm performance in Turkish manufacturing firms: an empirical study. International Entrepreneurship and Management Journal, 8(1), 15-33.

Alegre, J., \& Chiva, R. (2013). Linking Entrepreneurial Orientation and Firm Performance: The Role of Organizational Learning Capability and Innovation Performance. Journal of small business management, 51(4), 491-507. doi: 10.1111/jsbm.12005

Almodóvar, P., \& Rugman, A. M. (2014). The M Curve and the Performance of Spanish International New Ventures. British Journal of Management, 25(S1), S6-S23. doi: 10.1111/1467-8551.12022

Anderson, B. S., Covin, J. G., \& Slevin, D. P. (2009). Understanding the relationship between entrepreneurial orientation and strategic learning capability: an empirical investigation. Strategic Entrepreneurship Journal, 3(3), 218-240. doi: 10.1002/sej.72

Antoncic, B. (2007). Intrapreneurship: a comparative structural equation modeling study. Industrial Management \& Data Systems, 107(3), 309-325.

Antoncic, B., \& Hisrich, R. D. (2001). Intrapreneurship: Construct refinement and crosscultural validation. Journal of Business Venturing, 16(5), 495-527.

Antoncic, B., \& Hisrich, R. D. (2003). Clarifying the intrapreneurship concept. Journal of Small Business and Enterprise Development, 10(1), 7-24. doi: doi:10.1108/14626000310461187

Antoncic, B., \& Hisrich, R. D. (2004). Corporate entrepreneurship contingencies and organizational wealth creation. The Journal of Management Development, 23(5/6), 518-550.

Baker, W., \& Sinkula, J. (1999). The synergistic effect of market orientation and learning orientation on organizational performance. Journal of the Academy of Marketing Science, 27(4), 411-427. doi: 10.1177/0092070399274002

Barney, J. B. (1991). Firm resources and sustained competitive advantage. Journal of Management, 17(1), 99-120.

Baron, R. M., \& Kenny, D. A. (1986). The Moderator-Mediator Variable Distinction in Social Psychological Research: Conceptual, Strategic, and Statistical Considerations. Journal of Personality and Social Psychology, 51(6), 1173-1182.

Billing, T. K., Mukherjee, D., Kedia, B. L., \& Lahiri, S. (2010). Top executives' international expertise commitment: exploring potential antecedents. Leadership \& Organization Development Journal, 31(8), 687-704. doi: http://dx.doi.org/10.1108/01437731011094757

Birkinshaw, J. (1997). Entrepreneurship in Multinational Corporations: The Characteristics of Subsidiary Initiatives. Strategic Management Journal, 18(3), 207-229.

Boermans, M. A., \& Roelfsema, H. (2016). Small firm internationalization, innovation, and growth. International Economics and Economic Policy, 13(2), 283-296. doi: 10.1007/s10368-014-0310-y

Boso, N., Story, V. M., \& Cadogan, J. W. (2013). Entrepreneurial orientation, market orientation, network ties, and performance: Study of entrepreneurial firms in a developing economy. Journal of Business Venturing, 28(6), 708-727. doi: https://doi.org/10.1016/j.jbusvent.2013.04.001 
Brás, G. R., \& Soukiazis, E. (2019). The Determinants of Entrepreneurship at the Country Level: A Panel Data Approach. Entrepreneurship Research Journal, 9(4), 1-17. doi: https://doi.org/10.1515/erj-2016-0060

Brewer, H. L. (1981). Investor benefits from corporate international diversification. Journal of Financial and Quantitative Analysis, 16(1), 113-126.

Brouthers, K. D., Nakos, G., \& Dimitratos, P. (2015). SME Entrepreneurial Orientation, International Performance, and the Moderating Role of Strategic Alliances. Entrepreneurship Theory and Practice, 39(5), 1161-1187. doi: 10.1111/etap.12101

Brown, C. E. (1998). Coefficient of Variation Applied Multivariate Statistics in Geohydrology and Related Sciences (pp. 155-157). Berlin, Heidelberg: Springer Berlin Heidelberg.

Burton, E. L. (2015). The impact of risk aversion on economic development in Portugal. Perspectives on Business and Economics, 33(4), 26-38.

Byrne, B. M. (2013). Structural Equation Modeling With AMOS: Basic Concepts, Applications, and Programming (2nd, reviewed ed.). New York: Routledge.

Callaway, S. K. (2008). Global Corporate Ventures: A New Trend of International Corporate Entrepreneurship. Multinational Business Review, 16(3), 1-22.

Capar, N., \& Kotabe, M. (2003). The relationship between international diversification and performance in service firms. Journal of International Business Studies, 34(4), 345355.

Carvalho, M. I., Simões, J., Samagaio, A., \& Couto, E. (2012). Enterprise potential of Portuguese students fostered by an entrepreneurship education program. Paper presented at the European Conference on Innovation and Entrepreneurship.

Castrogiovanni, G. J., Urbano, D., \& Loras, J. (2011). Linking corporate entrepreneurship and human resource management in SMEs. International Journal of Manpower, 32(1), 3447. doi: http://dx.doi.org/10.1108/01437721111121215

Chang, J. (2000). Model of corporate entrepreneurship: intrapreneurship and exopreneurship. International Journal of Entrepreneurship, 4, 69-104.

Chen, H., \& Hsu, C.-W. (2010). Internationalization, resource allocation and firm performance. Industrial Marketing Management, 39(7), 1103-1110.

Cheung, G. W., \& Lau, R. S. (2008). Testing Mediation and Suppression Effects of Latent Variables: Bootstrapping With Structural Equation Models. Organizational Research Methods, 11(2), 296-325.

Christmann, H., Alexander, A., \& Wood, S. (2016). Exploring brand identity and entrepreneurship as drivers of small specialist retailer internationalisation: a German case study. The International Review of Retail, Distribution and Consumer Research, 26(2), 137-153. doi: 10.1080/09593969.2015.1080751

Colpan, A. M., Delios, A., \& Hikino, T. (2013). How does export commitment and product diversity affect the international scope-firm performance relationship?: Evidence from Japan. Asian Business \& Management, 12(1), 142-172. doi: http://dx.doi.org/10.1057/abm.2012.32

Contractor, F. J. (2007). Is international business good for companies? The evolutionary or multi-stage theory of internationalization vs. the transaction cost perspective. Management International Review, 47(3), 453-475.

Coulibaly, S. K., Erbao, C., \& Mekongcho, T. M. (2018). Economic globalization, entrepreneurship, and development. Technological Forecasting and Social Change, 127, 271-280. doi: https://doi.org/10.1016/j.techfore.2017.09.028

Coviello, N. E., Jones, M. V., \& McDougall-Covin, P. (2014). Is International Entrepreneurship research a viable spin-off from its parent disciplines? In A. Fayolle \& P. Riot (Eds.), Institutionalization of Entrepreneurship: Hopes and Pitfalls for Entrepreneurship Research: Routledge. 
Coviello, N. E., \& Munro, H. J. (1997). Network relationships and the internationalisation process of small software firms. International Business Review, 6(4), 361-386. doi: http://dx.doi.org/10.1016/S0969-5931(97)00010-3

Covin, J. G., \& Miles, M. P. (1999). Corporate entrepreneurship and the pursuit of competitive advantage. Entrepreneurship Theory and Practice, 23(3), 47-63.

Covin, J. G., \& Miller, D. (2014). International Entrepreneurial Orientation: Conceptual Considerations, Research Themes, Measurement Issues, and Future Research Directions. Entrepreneurship Theory and Practice, 38(1), 11-44. doi: 10.1111/etap. 12027

Covin, J. G., \& Slevin, D. P. (1989). Strategic management of small firms in hostile and benign environments. Strategic Management Journal, 10(1), 75-87. doi: 10.1002/smj.4250100107

Crick, D., \& Jones, M. V. (2000). Small High-Technology Firms and International HighTechnology Markets. Journal of International Marketing, 8(2), 63-85. doi: $10.2307 / 25048807$

Cumming, D., Fischer, E., \& Peridis, T. (2015). Publicly funded business advisory services and entrepreneurial internationalization. International small business journal, 33(8), 824-839. doi: 10.1177/0266242614537849

Dess, G. G., Ireland, R. D., Zahra, S. A., Floyd, S. W., Janney, J. J., \& Lane, P. J. (2003). Emerging Issues in Corporate Entrepreneurship. Journal of Management, 29(3), 351378.

Dimitratos, P., Plakoyiannaki, E., Pitsoulaki, A., \& Tuselmann, H. J. (2010). The global smaller firm in international entrepreneurship. International Business Review, 19(6), 589-606. doi: http://dx.doi.org/10.1016/j.ibusrev.2010.03.005

Duarte, N., Diniz, F., Arent, A., \& Bojar, M. (2013). Entrepreneurship Strategies in a Portuguese and in a Polish Region. Recent Advances in Business Management \& Marketing, 188-193.

Elango, B. (2006). An empirical analysis of the internationalization performance relationship across emerging market firms. Multinational Business Review, 14(1), 21-44.

Etemad, H. (2017). Towards a conceptual multilayered framework of international entrepreneurship. Journal of International Entrepreneurship, 15(3), 229-238. doi: $10.1007 / \mathrm{s} 10843-017-0212-5$

Etemad, H. (2018). Growth and learning mechanisms in the evolving multilayered and multidimensional view of international entrepreneurship. Journal of International Entrepreneurship, 16(1), 1-11. doi: 10.1007/s10843-018-0227-6

European Commission. (2020). European innovation scoreboard. Luxembourg: Publications Office of the European Union.

Farrell, M. A., Oczkowski, E., \& Kharabsheh, R. (2011). Antecedents and performance consequences of learning success in international joint ventures. Industrial Marketing Management, 40(3), 479-488. doi: 10.1016/j.indmarman.2009.11.001

Felício, J. A., Rodrigues, R., \& Caldeirinha, V. R. (2012). The effect of intrapreneurship on corporate performance. Management Decision, 50(10), 1717-1738. doi: http://dx.doi.org/10.1108/00251741211279567

Fernández-Olmos, M., Gargallo-Castel, A., \& Giner-Bagües, E. (2016). Internationalisation and performance in Spanish family SMES: The W-curve. BRQ Business Research Quarterly, 19(2), 122-136. doi: https://doi.org/10.1016/j.brq.2015.07.001

Ferreira, A. d. S. M., Loiola, E., \& Gondim, S. M. G. (2017). Motivations, business planning, and risk management: entrepreneurship among university students. RAI Revista de Administração e Inovação, 14(2), 140-150. 
Ferreira, J. (2007). Entrepreneurial Strategic Orientation as Determinant of Growth of the Small Firms of Manufacturing Industry: a Portuguese Case. Panorama Socioeconómico, 25(34), 34-47.

Fitzsimmons, J. R., Douglas, E. J., Antoncic, B., \& Hisrich, R. D. (2005). Intrapreneurship in Australian Firms. Journal of the Australian and New Zealand Academy of Management, 11(1), 17-27.

Fornell, C., \& Larcker, D. F. (1981). Evaluating Structural Equation Models with Unobservable Variables and Measurement. Journal of Marketing Research, 18, 39-50.

Franco, M., \& Haase, H. (2013). Firm resources and entrepreneurial orientation as determinants for collaborative entrepreneurship. Management Decision, 51(3), 680696. doi: http://dx.doi.org/10.1108/00251741311309724

Friedrich, T. L., Byrne, C. L., \& Mumford, M. D. (2009). Methodological and theoretical considerations in survey research. The Leadership Quarterly, 20(2), 57-60. doi: http://dx.doi.org/10.1016/j.leaqua.2009.01.001

George, B. A., \& Marino, L. (2011). The Epistemology of Entrepreneurial Orientation: Conceptual Formation, Modeling, and Operationalization. Entrepreneurship Theory and Practice, 35(5), 989-1024.

George, D., \& Mallery, P. (2010). SPSS for Windows Step by Step: A Simple Guide and Reference, 17.0 update. Boston: Pearson.

Glaum, M., \& Oesterle, M.-J. (2007). 40 years of research on internationalization and firm performance: More questions than answers? Management International Review, 47(3), 307-317.

Gomes, L., \& Ramaswamy, K. (1999). An empirical examination of the form of the relationship between multinationality and performance. Journal of International Business Studies, 30(1), 173-187.

Hair, J. F., Black, B., Anderson, R. E., \& Tatham, R. L. (2005). Multivariate Data Analysis. NJ: Prentice Hall.

Harman, H. H. (1976). Modern Factor Analysis: University of Chicago Press.

Hennart, J. F. (2007). The Theoretical Rationale for a Multinationality/Performance Relationship. Management International Review, 47(3), 423-452.

Hernández-Perlines, F., Ibarra Cisneros, M. A., Ribeiro-Soriano, D., \& Mogorrón-Guerrero, H. (2019). Innovativeness as a determinant of entrepreneurial orientation: analysis of the hotel sector. Economic Research-Ekonomska Istraživanja, 1-17. doi: 10.1080/1331677X.2019.1696696

Hornsby, J. S., Kuratko, D. F., \& Zahra, S. A. (2002). Middle managers' perception of the internal environment for corporate entrepreneurship: assessing a measurement scale. Journal of Business Venturing, 17(3), 253-273. doi: http://dx.doi.org/10.1016/S08839026(00)00059-8

Hsu, C.-C., \& Boggs, D. (2003). Internationalization and Performance: Traditional Measures and Their Decomposition. Multinational Business Review, 11(3), 23-49.

Hsu, W.-T., Chen, H.-L., \& Cheng, C.-Y. (2013). Internationalization and firm performance of SMEs: The moderating effects of CEO attributes. Journal of World Business, 48(1), 1-12. doi: https://doi.org/10.1016/j.jwb.2012.06.001

Hughes, M., \& Morgan, R. E. (2007). Deconstructing the relationship between entrepreneurial orientation and business performance at the embryonic stage of firm growth. Industrial Marketing Management, 36(5), 651-661. doi: https://doi.org/10.1016/j.indmarman.2006.04.003

Hughes, P., Hodgkinson, I. R., Hughes, M., \& Arshad, D. (2018). Explaining the entrepreneurial orientation-performance relationship in emerging economies: The intermediate roles of absorptive capacity and improvisation. Asia Pacific Journal of Management, 35(4), 1025-1053. doi: 10.1007/s10490-017-9539-7 
Ibeh, K. I. N. (2003). Toward a contingency framework of export entrepreneurship: Conceptualisations and empirical evidence. Small Business Economics, 20(1), 49-68.

Ireland, R. D., Covin, J. G., \& Kuratko, D. F. (2009). Conceptualizing Corporate Entrepreneurship Strategy. Entrepreneurship Theory and Practice, 33(1), 19-46. doi: http://dx.doi.org/10.1111/j.1540-6520.2008.00279.x

Jantunen, A., Puumalainen, K., Saarenketo, S., \& Kyläheiko, K. (2005). Entrepreneurial Orientation, Dynamic Capabilities and International Performance. Journal of International Entrepreneurship, 3(3), 223-243. doi: 10.1007/s10843-005-1133-2

Johanson, J., \& Mattsson, L. (1986). International marketing and internationalization processes - a Network Approach. In S. T. Paliwoda, P.W. (Ed.), Research in international marketing. London: Croom Helm.

Johanson, J., \& Mattsson, L. (1988). Internationalization in Industrial Systems - A Network Approach In e. Hood and Vahlne (Ed.), Strategies in Global Competition (pp. 303321). New York: Croom Helm.

Johanson, J., \& Vahlne, J. E. (1977). Internationalization Process of Firm - Model of Knowledge Development and Increasing Foreign Market Commitments. Journal of International Business Studies, 8(1), 23-32.

Johanson, J., \& Wiedersheimpaul, F. (1975). Internationalization of Firm - 4 Swedish Cases. Journal of Management Studies, 12(3), 305-322.

Kaiser, H. F. (1974). An index of factorial simplicity. Psychometrika, 39(1), 31-36. doi: $10.1007 / \mathrm{bf02291575}$

Kilic, K., Ulusoy, G., Gunday, G., \& Alpkan, L. (2015). Innovativeness, operations priorities and corporate performance: An analysis based on a taxonomy of innovativeness: JETM JET-M. Journal of Engineering and Technology Management, 35, 115-133.

Kim, H.-Y. (2013). Statistical notes for clinical researchers: assessing normal distribution (2) using skewness and kurtosis. Restorative dentistry \& endodontics, 38(1), 52-54. doi: 10.5395/rde.2013.38.1.52

Kline, R. B. (2011). Principles and practice of structural equation modeling (3rd ed.). New York: Guilford Press.

Knight, G. A. (2000). Entrepreneurship and Marketing Strategy: The SME Under Globalization. Journal of International Marketing, 8(2), 12-32. doi: 10.1509/jimk.8.2.12.19620

Knight, G. A., \& Cavusgil, S. T. (2004). Innovation, organizational capabilities, and the bornglobal firm. Journal of International Business Studies, 35(2), 124-141.

Knight, G. A., \& Kim, D. (2009). International business competence and the contemporary firm. Journal of International Business Studies, 40(2), 255-273. doi: http://dx.doi.org/10.1057/palgrave.jibs.8400397

Kollmann, T., \& Stöckmann, C. (2014). Filling the Entrepreneurial Orientation-Performance Gap: The Mediating Effects of Exploratory and Exploitative Innovations. Entrepreneurship Theory and Practice, 38(5), 1001-1026. doi: 10.1111/j.15406520.2012.00530.x

Kreiser, P. M., Kuratko, D. F., Covin, J. G., Ireland, R. D., \& Hornsby, J. S. (2019). Corporate entrepreneurship strategy: extending our knowledge boundaries through configuration theory. Small Business Economics, in press. doi: 10.1007/s11187-019-00198-x

Kreiser, P. M., Marino, L. D., \& Weaver, K. M. (2002). Assessing the psychometric properties of the entrepreneurial orientation scale: A multi-country analysis. Entrepreneurship Theory and Practice, 26(4), 71-94.

Kuivalainen, O., Puumalainen, K., Sintonen, S., \& Kylaheiko, K. (2010). Organisational capabilities and internationalisation of the small and medium-sized information and communications technology firms. Journal of International Entrepreneurship, 8(2), 135-155. doi: 10.1007/s10843-010-0057-7 
Kuratko, D. F., \& Audretsch, D. B. (2013). Clarifying the Domains of Corporate Entrepreneurship. International Entrepreneurship and Management Journal, 9(3), 323-335. doi: http://dx.doi.org/10.1007/s11365-013-0257-4

Kyrgidou, L. P., \& Spyropoulou, S. (2013). Drivers and Performance Outcomes of Innovativeness: An Empirical Study. British Journal of Management, 24(3), 281-298.

Lee, T., \& Chu, W. (2017). The relationship between entrepreneurial orientation and firm performance: Influence of family governance. Journal of Family Business Strategy, 8(4), 213-223. doi: https://doi.org/10.1016/j.jfbs.2017.09.002

Lim, E., \& Kim, D. (2020). Entrepreneurial Orientation and Performance in South Korea: The Mediating Roles of Dynamic Capabilities and Corporate Entrepreneurship. Entrepreneurship Research Journal, 10(3), 20160075. doi: https://doi.org/10.1515/erj-2016-0075

Lin, W.-T., Liu, Y., \& Cheng, K.-Y. (2011). The internationalization and performance of a firm: Moderating effect of a firm's behavior. Journal of International Management, 17(1), 83-95. doi: 10.1016/j.intman.2010.12.004

Lintukangas, K., Kähkönen, A.-K., \& Hallikas, J. (2019). The role of supply management innovativeness and supplier orientation in firms' sustainability performance. Journal of Purchasing and Supply Management, 25(4), 100558. doi: https://doi.org/10.1016/j.pursup.2019.100558

Loncan, T., \& Nique, W. M. (2010). Degree of Internationalization and performance: Evidence from emerging Brazilian multinational firms. Journal of Globalization, Competitiveness \& Governability, 4(1), 40-51.

Lu, J. W., \& Beamish, P. W. (2001). The internationalization and performance of SMEs. Strategic Management Journal, 22(6/7), 565-586.

Lu, J. W., \& Beamish, P. W. (2004). International diversification and firm performance: The S-curve hypothesis. Academy of Management journal, 47(4), 598-609.

Lumpkin, G. T., \& Dess, G. G. (1996). Clarifying the Entrepreneurial Orientation Construct and Linking it to Performance. Academy of Management Review, 21(1), 135-172.

Macmillan, I. C., Block, Z., \& Narasimha, P. N. S. (1986). Corporate venturing: alternatives, obstacles encountered, and experience effects. Journal of Business Venturing, 1(2), 177-191. doi: http://dx.doi.org/10.1016/0883-9026(86)90013-3

Mardia, K. V. (1970). Measures of Multivariate Skewness and Kurtosis with Applications. Biometrika, 57(3), 519-530. doi: 10.2307/2334770

Marôco, J. (2010). Análise de Equações Estruturais: Fundamentos teóricos, Software e Aplicações Pêro Pinheiro: ReportNumber, Lda.

Marr, B., \& Schiuma, G. (2003). Business performance measurement - past, present, and future. Management Decision, 41(8), 680-687.

Martiarena, A. (2013). What's so entrepreneurial about intrapreneurs? Small Business Economics, 40(1), 27-39.

McDougall-Covin, P., Jones, M. V., \& Serapio, M. G. (2014). High-Potential Concepts, Phenomena, and Theories for the Advancement of International Entrepreneurship Research. Entrepreneurship Theory and Practice, 38(1), 1-10. doi: http://dx.doi.org/10.1111/etap.12090

McDougall, P. P., \& Oviatt, B. M. (1996). New venture internationalization, strategic change, and performance: A follow-up study. Journal of Business Venturing, 11(1), 23-40. doi: http://dx.doi.org/10.1016/0883-9026(95)00081-X

McDougall, P. P., \& Oviatt, B. M. (2000). International entrepreneurship: the intersection of two research paths. Academy of Management journal, 43(5), 902-906.

McDougall, P. P., \& Oviatt, B. M. (2005). The internationalization of entrepreneurship. Journal of International Business Studies, 36(1), 2-8. 
Mejri, K., \& Umemoto, K. (2010). Small- and medium-sized enterprise internationalization: Towards the knowledge-based model. Journal of International Entrepreneurship, 8(2), 156-167. doi: 10.1007/s10843-010-0058-6

Meyskens, M., Robb-Post, C., Stamp, J. A., Carsrud, A. L., \& Reynolds, P. D. (2010). Social Ventures from a Resource-Based Perspective: An Exploratory Study Assessing Global Ashoka Fellows. Entrepreneurship Theory and Practice, 34(4), 661-680. doi: 10.1111/j.1540-6520.2010.00389.x

Moen, Ø., Heggeseth, A. G., \& Lome, O. (2016). The Positive Effect of Motivation and International Orientation on SME Growth. Journal of small business management, 54(2), 659-678. doi: 10.1111/jsbm.12163

Mohamad, O., Ramayah, T., Puspowarsito, H., Natalisa, D., \& Saerang, D. P. E. (2011). Corporate Entrepreneurship and Firm Performance: The Role of Business Environment as a Moderator[dagger]. IUP Journal of Management Research, 10(3), 7-27.

Morris, M. H., Webb, J. W., \& Franklin, R. J. (2011). Understanding the manifestation of entrepreneurial orientation in the nonprofit context. Entrepreneurship Theory and Practice, 35(5), 947-971.

Nummela, N., Saarenketo, S., \& Puumalainen, K. (2004). Attitude towards internationalization - a prerequisite for successful internationalization? Canadian Journal of Administrative Sciences,, 21(1), 51-64.

OECD. (2014). Entrepreneurship at a Glance 2014: OECD Publishing.

Ou-Yang, H.-Y., Chaisingharn, N., \& Nguyen, T. H. (2016). The impacts of entrepreneurship on export orientation and internationalisation: the moderating effects of family ownership and involvement. International Journal of Innovation and Learning, 19(1), $1-24$.

Oviatt, B. M., \& McDougall, P. P. (1994). Toward a Theory of International New ventures. Journal of International Business Studies, 25(1), 45-64.

Oviatt, B. M., \& McDougall, P. P. (2005). Defining International Entrepreneurship and Modeling the Speed of Internationalization. Entrepreneurship Theory and Practice, 29(5), 537-554. doi: 10.1111/j.1540-6520.2005.00097.x

Pangarkar, N. (2008). Internationalization and performance of small- and medium-sized enterprises. Journal of World Business, 43(4), 475-485. doi: http://dx.doi.org/10.1016/j.jwb.2007.11.009

Parker, S. C. (2011). Intrapreneurship or entrepreneurship? Journal of Business Venturing, 26(1), 19-34.

Peng, M. W. (2001). The resource-based view and international business. Journal of Management, 27, 803-829.

Penrose, E. T. (1959). The Theory of the Growth of the Firm. Oxford: Oxford University Press.

Phan, P. H., Wright, M., Ucbasaran, D., \& Tan, W.-L. (2009). Corporate entrepreneurship: Current research and future directions. Journal of Business Venturing, 24(3), 197-205. doi: http://dx.doi.org/10.1016/j.jbusvent.2009.01.007

Pinchot, G. (1986). Intrapreneuring: why you don't have to leave the corporation to become an entrepreneur: Harper \& Row.

Pinho, J. C., \& Prange, C. (2016). The effect of social networks and dynamic internationalization capabilities on international performance. Journal of World Business, 51(3), 391-403. doi: https://doi.org/10.1016/j.jwb.2015.08.001

Podsakoff, P. M., MacKenzie, S. B., Lee, J.-Y., \& Podsakoff, N. P. (2003). Common method biases in behavioral research: A critical review of the literature and recommended remedies. Journal of Applied Psychology, 88(5), 879-903.

Powell, K. S. (2014). From M-P to MA-P: Multinationality alignment and performance. Journal of International Business Studies, 45(2), 211-226. doi: 10.1057/jibs.2013.63 
Preacher, K. J., \& Hayes, A. F. (2008). Asymptotic and resampling strategies for assessing and comparing indirect effects in multiple mediator models. Behavior Research Methods, 40(3), 879-891. doi: 10.3758/BRM.40.3.879

Provasnek, A. K., Schmid, E., Geissler, B., \& Steiner, G. (2017). Sustainable Corporate Entrepreneurship: Performance and Strategies Toward Innovation. Business Strategy and the Environment, 26(4), 521-535. doi: 10.1002/bse.1934

Putniņš, T. J., \& Sauka, A. (2019). Why does entrepreneurial orientation affect company performance? Strategic Entrepreneurship Journal, In press. doi: https://doi.org/10.1002/sej.1325

Racela, O. C., Chaikittisilpa, C., \& Amonrat, T. (2007). Market orientation, international business relationships and perceived export performance. International Marketing Review, 24(2), 144-163. doi: http://dx.doi.org/10.1108/02651330710741794

Ramaswamy, K. (1992). Multinationality and performance: A synthesis and redirection. Advances in International Comparative Management, 7, 241-267.

Rauch, A., Wiklund, J., Lumpkin, G. T., \& Frese, M. (2009). Entrepreneurial Orientation and Business Performance: An Assessment of Past Research and Suggestions for the Future. Entrepreneurship: Theory \& Practice, 33(3), 761-787. doi: 10.1111/j.15406520.2009.00308.x

Ray, G., Barney, J. B., \& Muhanna, W. A. (2004). Capabilities, business processes, and competitive advantage: choosing the dependent variable in empirical tests of the resource-based view. Strategic Management Journal, 25(1), 23-37.

Rezaei, J., \& Ortt, R. (2018). Entrepreneurial orientation and firm performance: the mediating role of functional performances. Management Research Review, 41(7), 878-900. doi: 10.1108/MRR-03-2017-0092

Rezaei, J., Ortt, R., \& Scholten, V. (2012). Measuring entrepreneurship: Expert-based vs. databased methodologies. Expert Systems with Applications, 39(4), 4063-4074. doi: http://dx.doi.org/10.1016/j.eswa.2011.09.091

Ripollés-Meliá, M., Menguzzato-Boulard, M., \& Sánchez-Peinado, L. (2007). Entrepreneurial orientation and international commitment. Journal of International Entrepreneurship, 5(3-4), 65-83. doi: 10.1007/s10843-007-0016-0

Ripollés, M., Blesa, A., \& Monferrer, D. (2012). Factors enhancing the choice of higher resource commitment entry modes in international new ventures. International Business Review, 21(4), 648-666. doi: http://dx.doi.org/10.1016/j.ibusrev.2011.07.007

Rodrigues, R. G., \& Raposo, M. (2011). Entrepreneurial Orientation, Human Resources Information Management, and Firm Performance in SMEs. Canadian Journal of Administrative Sciences / Revue Canadienne des Sciences de l'Administration, 28(2), 143-153. doi: 10.1002/cjas.205

Rossmannek, O., \& Rank, O. (2019). Internationalization of exploitation alliance portfolios and firm performance. Management Decision, 57(1), 86-99.

Ruigrok, W., \& Wagner, H. (2004). Internationalization and Firm Performance: Meta-analytic Review and Future Research Directions. Working Paper, University of St. Gallen.

Rutherford, M. W., \& Holt, D. T. (2007). Corporate entrepreneurship: An empirical look at the innovativeness dimension and its antecedents. Journal of organizational change Management, 20(3), 429-446.

Samiee, S., Walters, P. G. P., \& DuBois, F. L. (1993). Exporting as an Innovative Behaviour: An Empirical Investigation. International Marketing Review, 10(3), 5-25.

Schollhammer, H. (1982). Internal Corporate Entrepreneurship. In C. Kent, D. Sexton, \& K. Vesper (Eds.), Encyclopaedia of Entrepreneurship. Englewood Clipp, NJ.: Prentice Hall. 
Schwens, C., Zapkau, F. B., Bierwerth, M., Isidor, R., Knight, G., \& Kabst, R. (2018). International entrepreneurship: a meta-analysis on the internationalization and performance relationship. Entrepreneurship Theory and Practice, 42(5), 734-768.

Semrau, T., Ambos, T., \& Sascha, K. (2016). Entrepreneurial orientation and SME performance across societal cultures: An international study. Journal of Business Research, 69(5), 1928-1932. doi: https://doi.org/10.1016/j.jbusres.2015.10.082

Simmonds, K., \& Smith, H. (1968). The first export order: a marketing innovation. European Journal of Marketing, 2(2), 93-100.

Sirgy, M. J. (2002). Measuring Corporate Performance by Building on the Stakeholders Model of Business Ethics. Journal of Business Ethics, 35(3), 143-162. doi: 10.1023/a: 1013856421897

Slater, S. F., \& Narver, J. C. (2000). The positive effect of a market orientation on business profitability: A balanced replication. Journal of Business Research, 48(1), 69-73.

Song, M., Wang, T., \& Parry, M. E. (2010). Do market information processes improve new venture performance? Journal of Business Venturing, 25(6), 556-568. doi: http://dx.doi.org/10.1016/j.jbusvent.2009.03.003

Sullivan, D. (1994). Measuring the degree of internationalization of a firm. Journal of International Business Studies, 25(2), 325-342.

Swain, S. D., Weathers, D., \& Niedrich, R. W. (2008). Assessing three sources of misresponse to reversed Likert items. Journal of Marketing Research, 45(1), 116-131. doi: $10.1509 / \mathrm{jmkr} .45 .1 .116$

Teece, D. J. (1982). Towards an economic theory of the multiproduct firm. Journal of Economic Behaviour and Organization, 3, 39-63.

Tenenhaus, M., Vinzi, V. E., Chatelin, Y. M., \& Lauro, C. (2005). PLS path modeling. Computational Statistics \& Data Analysis, 48, 159-205.

Teo, T. S. H., Srivastava, S. C., \& Jiang, L. (2008). Trust and Electronic Government Success: An Empirical Study. Journal of Management Information Systems, 25(3), 99-131.

Ullman, J. B. (2007). Structural Equation Modeling. In B. G. Tabachnick \& L. S. Fidell (Eds.), Using multivariate statistics (pp. 676-780). Boston: Pearson Education.

Urbano, D., Álvarez, C., \& Turró, A. (2013). Organizational resources and intrapreneurial activities: an international study. Management Decision, 51(4), 854-870. doi: http://dx.doi.org/10.1108/00251741311326617

Van Doorn, S., Heyden, M., Tröster, C., \& Volberda, H. (2015). Entrepreneurial orientation and performance: Investigating local requirements for entrepreneurial decisionmaking. In G. Cattani (Ed.), Cognition and Strategy (pp. 211-239): Emerald Group Publishing Limited.

Wang, C. L. (2008). Entrepreneurial Orientation, Learning Orientation, and Firm Performance. Entrepreneurship Theory and Practice, 32(4), 635-657. doi: 10.1111/j.1540-6520.2008.00246.x

Wennekers, S., \& Thurik, R. (1999). Linking entrepreneurship and economic growth. Small Business Economics, 13(1), 27-55.

Wernerfelt, B. (1984). A resource-based view of the firm. Strategic Management Journal, 5(2), 171-180. doi: 10.1002/smj.4250050207

Wieland, A., Durach Christian, F., Kembro, J., \& Treiblmaier, H. (2017). Statistical and judgmental criteria for scale purification. Supply Chain Management: An International Journal, 22(4), 321-328. doi: 10.1108/SCM-07-2016-0230

Wiklund, J., \& Shepherd, D. (2003). Knowledge-based resources, entrepreneurial orientation, and the performance of small and medium-sized businesses. Strategic Management Journal, 24(13), 1307-1314. doi: 10.1002/smj.360 
Wiklund, J., \& Shepherd, D. (2005). Entrepreneurial Orientation and Small Business Performance: A Configurational Approach. Journal of Business Venturing, 20(1), 7191.

Yang, Y., \& Ju, X. F. (2017). Entrepreneurial Orientation and Firm Performance: Is Product Quality a Missing Link? Entrepreneurship Research Journal, 8(1), 1-15. doi: 10.1515/erj-2017-0091

Yiu, D. W., Lau, C., \& Bruton, G. D. (2007). International venturing by emerging economy firms: the effects of firm capabilities, home country networks, and corporate entrepreneurship. J Int Bus Stud, 38(4), 519-540.

Yli-Renko, H., Autio, E., \& Tontti, V. (2002). Social capital, knowledge, and the international growth of technology-based new firms. International Business Review, 11(3), 279304. doi: http://dx.doi.org/10.1016/S0969-5931(01)00061-0

Yuan, K.-H., Marshall, L., \& Bentler, P. M. (2002). A unified approach to exploratory factor analysis with missing data, nonnormal data, and in the presence of outliers. Psychometrika, 67(1), 95-121. doi: 10.1007/bf02294711

Zahra, S. A. (1991). Predictors and financial outcomes of corporate entrepreneurship: An exploratory study. Journal of Business Venturing, 6(4), 259-285.

Zahra, S. A., \& Covin, J. G. (1995). Contextual influences on the corporate entrepreneurshipperformance relationship: A longitudinal analysis. Journal of Business Venturing, $10(1), 43-58$.

Zahra, S. A., \& Garvis, D. M. (2000). International corporate entrepreneurship and firm performance: The moderating effect of international environmental hostility. Journal of Business Venturing, 15(5,6), 469-492.

Zahra, S. A., \& George, G. (2002). International entrepreneurship: The current status of the field and future research agenda. In Hitt, Ireland, Camp, \& Sexton (Eds.), Strategic Entrepreneurship: Creating an Integrated Mindset (pp. 255-288): Oxford, Blackwell Publishers.

Zahra, S. A., Ireland, R. D., \& Hitt, M. A. (2000). International Expansion by New Venture Firms: International Diversity, Mode of Market Entry, Technological Learning, and Performance. Academy of Management journal, 43(5), 925-950.

Zahra, S. A., Neubaum, D. O., \& Huse, M. (2000). Entrepreneurship in medium-size companies: Exploring the effects of ownership and governance systems. Journal of Management, 26(5), 947-976.

Zajac, E. J., Golden, B. R., \& Shortell, S. M. (1991). New Organizational Forms for Enhancing Innovation: The Case of Internal Corporate Joint Ventures. Management Science, 37(2), 170-184. doi: 10.2307/2632389

Zehir, C., Can, E., \& Karaboga, T. (2015). Linking Entrepreneurial Orientation to Firm Performance: The Role of Differentiation Strategy and Innovation Performance. Procedia - Social and Behavioral Sciences, 210, 358-367. doi: https://doi.org/10.1016/j.sbspro.2015.11.381 
Appendix 1: Descriptive Statistics

\begin{tabular}{|c|c|c|c|c|c|c|c|c|}
\hline Variables & $\mathrm{N}$ & Minimum & Maximum & Mean & Std. Deviation & Skewness & Kurtosis & $\begin{array}{c}\text { Coeff. } \\
\text { Variation }\end{array}$ \\
\hline Inov1 & 341 & 1 & 5 & 3.57 & 1.008 & -0.804 & 0.169 & 0.282 \\
\hline Inov2 & 341 & 1 & 5 & 4.04 & 0.839 & -1.189 & 1.758 & 0.208 \\
\hline Inov3 & 341 & 1 & 5 & 3.62 & 0.911 & -0.729 & 0.067 & 0.252 \\
\hline Pro1 & 341 & 1 & 5 & 3.48 & 0.925 & -0.322 & -0.666 & 0.266 \\
\hline Pro2 & 341 & 1 & 5 & 3.21 & 0.942 & -0.165 & -0.419 & 0.293 \\
\hline Pro3 & 341 & 1 & 5 & 2.83 & 1.191 & 0.07 & -1.146 & 0.421 \\
\hline Risk1 & 341 & 1 & 5 & 2.25 & 0.804 & 1.43 & 2.324 & 0.357 \\
\hline Risk2 & 341 & 1 & 5 & 2.28 & 0.95 & 0.673 & -0.198 & 0.417 \\
\hline IO1 & 341 & 1 & 5 & 4.03 & 0.95 & -1.101 & 0.986 & 0.236 \\
\hline $\mathrm{IO} 2$ & 341 & 2 & 5 & 4.09 & 0.673 & -0.807 & 1.684 & 0.165 \\
\hline IO3 & 341 & 1 & 5 & 3.77 & 0.93 & -0.919 & 0.724 & 0.247 \\
\hline IO4 & 341 & 1 & 5 & 3.76 & 0.866 & -0.794 & 0.693 & 0.230 \\
\hline IO5 & 341 & 1 & 5 & 2.54 & 0.902 & 0.727 & -0.36 & 0.355 \\
\hline IO6 & 341 & 1 & 5 & 2.33 & 0.796 & 1.092 & 0.935 & 0.342 \\
\hline IO7 & 341 & 1 & 5 & 2.4 & 0.988 & 0.561 & -0.53 & 0.412 \\
\hline IO8 & 341 & 1 & 5 & 3.81 & 0.899 & -0.985 & 0.913 & 0.236 \\
\hline IO9 & 341 & 1 & 5 & 3.4 & 1.012 & -0.562 & -0.452 & 0.298 \\
\hline IO10 & 341 & 1 & 5 & 3.93 & 0.777 & -1.129 & 2.261 & 0.198 \\
\hline IO11 & 341 & 1 & 5 & 4.13 & 0.631 & -0.951 & 3.766 & 0.153 \\
\hline Perf1 & 341 & 2 & 5 & 4.03 & 0.778 & -0.73 & 0.527 & 0.193 \\
\hline Perf2 & 341 & 1 & 5 & 3.75 & 0.771 & -0.538 & 0.332 & 0.206 \\
\hline Perf3 & 341 & 1 & 5 & 3.36 & 0.983 & -0.393 & -0.309 & 0.293 \\
\hline Perf4 & 341 & 1 & 5 & 3.27 & 0.867 & -0.232 & -0.206 & 0.265 \\
\hline Perf5 & 341 & 1 & 5 & 3.6 & 0.794 & -0.494 & -0.043 & 0.221 \\
\hline
\end{tabular}

\section{Appendix 2: HTMT matrix}

\begin{tabular}{|l|l|l|l|}
\hline & EO & IO & Perf \\
\hline EO & $\mathbf{1}$ & & \\
\hline IO & 0,688 & 1 & \\
\hline Performance & 0,444 & 0,466 & 1 \\
\hline
\end{tabular}


Appendix 3: Standardised Regression Weights (with bootstrap)

\begin{tabular}{lllllll}
\hline Parameter & & & Estimate & Lower & Upper & P \\
\hline IO & $<-$ & EO & .677 & .557 & .785 & .001 \\
Performance & $<-$ & IO & .326 & .079 & .546 & .003 \\
Performance & $<-$ & EO & .189 & -.045 & .434 & .047 \\
Innov1 & $<-$ & EO & .577 & .447 & .681 & .001 \\
Innov2 & $<-$ & EO & .687 & .578 & .771 & .002 \\
Innov3 & $<-$ & EO & .770 & .665 & .853 & .001 \\
Pro2 & $<-$ & EO & .593 & .468 & .699 & .001 \\
IO1 & $<-$ & IO & .537 & .413 & .636 & .001 \\
IO2 & $<-$ & IO & .706 & .608 & .780 & .001 \\
IO3 & $<-$ & IO & .791 & .715 & .855 & .001 \\
IO4 & $<-$ & IO & .765 & .679 & .833 & .001 \\
IO8 & $<-$ & IO & .631 & .516 & .716 & .002 \\
IO9 & $<-$ & IO & .606 & .489 & .704 & .001 \\
IO10 & $<-$ & IO & .693 & .598 & .772 & .001 \\
IO11 & $<-$ & IO & .675 & .579 & .759 & .001 \\
Perf1 & $<-$ & Performance & .526 & .414 & .633 & .001 \\
Perf3 & $<-$ & Performance & .841 & .782 & .888 & .001 \\
Perf4 & $<-$ & Performance & .848 & .790 & .890 & .002 \\
Perf5 & $<-$ & Performance & .908 & .861 & .946 & .001 \\
\hline
\end{tabular}


Appendix 4: Standardised Regression Weights (without bootstrap)

\begin{tabular}{lllll}
\hline & & & Estimate & $\mathrm{P}$ \\
\hline IO & $<-$ & EO & .677 & $* * *$ \\
Performance & $<-$ & IO & .326 & $* * *$ \\
Performance & $<-$ & EO & .189 & .044 \\
Inov1 & $<-$ & EO & .577 & \\
Inov2 & $<-$ & EO & .687 & $* * *$ \\
Inov3 & $<-$ & EO & .770 & $* * *$ \\
Pro2 & $<-$ & EO & .593 & $* * *$ \\
IO1 & $<-$ & IO & .537 & \\
IO2 & $<-$ & IO & .706 & $* * *$ \\
IO3 & $<-$ & IO & .791 & $* * *$ \\
IO4 & $<-$ & IO & .765 & $* * *$ \\
IO8 & $<-$ & IO & .631 & $* * *$ \\
IO9 & $<-$ & IO & .606 & $* * *$ \\
IO10 & $<-$ & IO & .693 & $* * *$ \\
IO11 & $<-$ & IO & .675 & $* * *$ \\
Perf1 & $<-$ & Performance & .526 & \\
Perf3 & $<-$ & Performance & .841 & $* * *$ \\
Perf4 & $<-$ & Performance & .848 & $* * *$
\end{tabular}

Appendix 5: Indirect Effects - Two Tailed Significance (BC) by bootstrapping

\begin{tabular}{|l|rrr|}
\hline & EO & IO & Performance \\
\hline IO & $\ldots$ & $\ldots$ & $\ldots$ \\
Performance &, 001 & $\ldots$ & $\ldots$ \\
Perf5 &, 001 &, 003 & $\ldots$ \\
Perf4 &, 001 &, 003 & $\ldots$ \\
Perf3 &, 001 &, 003 & $\ldots$ \\
Perf1 &, 001 &, 002 & $\ldots$ \\
IO11 &, 001 & $\ldots$ & $\ldots$ \\
IO10 &, 001 & $\ldots$ & $\ldots$ \\
IO9 &, 001 & $\ldots$ & $\ldots$ \\
IO8 &, 001 & $\ldots$ & $\ldots$ \\
IO4 &, 001 & $\ldots$ & $\ldots$ \\
IO3 &, 001 & $\ldots$ & $\ldots$ \\
IO2 &, 001 & $\ldots$ & $\ldots$ \\
IO1 &, 001 & $\ldots$ & $\ldots$ \\
Pro2 & $\ldots$ & $\ldots$ & $\ldots$ \\
Inov3 & $\ldots$ & $\ldots$ & $\ldots$ \\
Inov2 & $\ldots$ & $\ldots$ & $\ldots$ \\
Inov1 & $\ldots$ & $\ldots$ & \\
\hline
\end{tabular}

